University of New Hampshire

University of New Hampshire Scholars' Repository

2012

\title{
Submarine landslides on the upper southeast Australian passive continental margin - preliminary findings
}

\author{
S L. Clarke \\ University of Sydney, Australia \\ T Hubble \\ University of Sydney, Australia \\ D Airey \\ University of Sydney, Australia \\ Phyllis Yu \\ University of Sydney, Australia \\ R Boyd \\ University of Newcastle - Australia
}

\section{Seetow nexp page for additional author:S \\ Part of the Computer Sciences Commons, and the Oceanography and Atmospheric Sciences and Meteorology Commons}

\section{Recommended Citation}

Clarke, S L.; Hubble, T; Airey, D; Yu, Phyllis; Boyd, R; Keene, J; Exon, N; and Gardner, James V., "Submarine landslides on the upper southeast Australian passive continental margin - preliminary findings" (2012). International symposium on submarine mass movements and their consequences. 663.

https://scholars.unh.edu/ccom/663

This Conference Proceeding is brought to you for free and open access by the Center for Coastal and Ocean Mapping at University of New Hampshire Scholars' Repository. It has been accepted for inclusion in Center for Coastal and Ocean Mapping by an authorized administrator of University of New Hampshire Scholars' Repository. For more information, please contact Scholarly.Communication@unh.edu. 


\section{Authors}

S L. Clarke, T Hubble, D Airey, Phyllis Yu, R Boyd, J Keene, N Exon, and James V. Gardner 


\title{
Submarine landslides on the upper southeast Australian passive continental margin - preliminary findings
}

\author{
Samantha Clarke ${ }^{1}$, Thomas Hubble ${ }^{1}$, David Airey ${ }^{1}$, Phyllis $\mathrm{Yu}^{1}$, Ron Boyd ${ }^{2,5}$, John Keene ${ }^{1}$, Neville Exon ${ }^{4}$, James \\ Gardner $^{3}$ and Shipboard Party SS12/2008 \\ 1. University of Sydney, Sydney, NSW, Australia.samantha.clarke@sydney.edu.au \\ 2. University of Newcastle, Newcastle, NSW, Australia \\ 3. CCOM, University of New Hampshire, Durham, NH, United States \\ 4. Earth and Marine Sciences, Australian National University, Canberra, ACT, Australia \\ 5. ConocoPhillips, Houston, TX, United States
}

\begin{abstract}
The southeast Australian passive continental margin is narrow, steep and sediment-deficient, and characterized by relatively low rates of modern sedimentation. Upper slope $(<1200 \mathrm{~m})$ sediments comprise mixtures of calcareous and terrigenous sand and mud. Three of twelve sediment cores recovered from geologically-recent, submarine landslides located offshore New South Wales/Queensland (NSW/QLD) are interpreted to have sampled failure surfaces at depths of between $85 \mathrm{~cm}$ and $220 \mathrm{~cm}$ below the present-day seabed. Differences in sediment physical properties are recorded above and below the three slide-plane boundaries. Sediment taken directly above the inferred submarine landslide failure surfaces and presumed to be post-landslide, returned radiocarbon ages of $15.8 \mathrm{ka}, 20.7 \mathrm{ka}$ and $20.1 \mathrm{ka}$. The last two ages correspond to adjacent slide features, which are inferred to be consistent with their being triggered by a single event such as an earthquake. Slope stability models based on classical soil mechanics and measured sediment shearstrengths indicate that the upper slope sediments should be stable. However, multibeam sonar data reveal that many upper slope landslides occur across the margin and that submarine landsliding is a common process. We infer from these results that: a) an unidentified mechanism regularly acts to reduce the shear resistance of these sediments to the very low values required to enable slope failure, and/or b) the margin experiences seismic events that act to destabilise the slope sediments.
\end{abstract}

Keywords: Mass-failure, multibeam, seafloor geomorphology, continental slope.

\section{Project Details}

The aim of this project is to determine the timing and improve our understanding of the causes of several recent examples of large number of submarine landslides that present on the entire length of the continental slope of the southeastern (SE) Australian margin. The research aims to: (1) define the age, morphology, composition and origin of particular submarine landslides on the SE Australian upper continental margin recently discovered offshore New South Wales/Queensland (NSW/QLD); (2) investigate, for the first time, the mechanical characteristics of sediments from the upper SE Australian continental slope; (3) answer the two important questions, when and why have slope failures occurred; (4) improve risk assessment and understanding of the tsunami hazard along this margin.

Submarine mass failures have been common throughout geological history; particularly on inclined seafloor slopes, areas where sedimentation rates are high, sediments are fine-grained, or seafloor rocks are weakened by fractures. Failures are thought to be triggered by a variety of stressors that dramatically reduce 
sediment shear strength and include: earthquakes, sea level fluctuations, tectonic events, gas hydrate dissociation, storms waves, and sedimentation. Individual failures can involve the movement of volumes of material reported to be as large as $20,000 \mathrm{~km}^{3}$ over distances of more than $140 \mathrm{~km}$ (Hampton et al. 1996).

Despite extensive literature on the nature and causes of submarine landslide, their dynamics and triggering processes are not well understood (Locat and Lee 2002; Bardet et al. 2003; Mosher et al. 2010). This lack of understanding partly results from the limited data on the physical and mechanical properties of sediments from the slide plane, as these materials are not usually collected.

In the Australian context, only a few studies have investigated submarine landslides on the Australian continental slopes. While evidence of submarine landslides on the southeastern (SE) Australian margin was first reported by Jenkins and Keene (1992), it was not until high resolution, multibeam bathymetric data became available (Glenn et al. 2008; Boyd et al. 2009) that the extent and ubiquity of these slides has been established. The preliminary investigations arising from the RV Southern Surveyor research cruise (SS12/2008) established that some, if not many, of the large submarine landslides located on the eastern Australian coastal margin offshore the Byron Bay area are geologically young (Boyd et al. 2009, 2010; Clarke et al. 2011).

This project addresses fundamental questions about the timing and mechanisms responsible for submarine landslides along Australia's SE continental margin, based on a unique data set collected on the $R V$ Southern Surveyor research cruise (SS12/2008) (Boyd et al. 2009, 2010). The study area is located along the SE Australian continental margin off northern New South Wales and southern Queensland (Fig. 1). To date, preliminary work has shown that the upper slope sediments are comprised of mixtures of calcareous and terrigenous sand and mud. Three of twelve cores collected during the Southern Surveyor cruise at separate sites located offshore NSW/QLD probably penetrated large, geologically-recent, submarine landslide failure surfaces at depths of between $60 \mathrm{~cm}$ and $200 \mathrm{~cm}$ below the present-day seabed (Fig. 2). Distinct differences in sediment physical properties have been determined for material immediately above and below the three slide-plane boundaries. Three preliminary ${ }^{14} \mathrm{C}$ ages from sediment presumed to be post-slide yield dates of $15.8 \mathrm{ka}, 20.7 \mathrm{ka}$ and $20.1 \mathrm{ka}$ directly above the inferred submarine landslide failure surfaces. The last two ages were determined for adjacent but distinct slide features, which is consistent with their being triggered by a single event such as an earthquake.

Slope stability models based on classical soil mechanics and measured sediment shear-strengths indicate that the upper slope sediments should be stable. However, the ubiquity of upper slope slides across the margin indicates that their occurrence is a relatively common event; and that submarine sliding is a frequent process on this margin. While this presents something of an interpretational paradox, it nevertheless indicates that either a) an unidentified mechanism regularly acts to reduce the shear resistance of these sediments to the very low values required to enable slope failure or b) the margin experiences earthquakes large enough to destabilise the slope sediments relatively frequently.

Detailed characterization of the slope sediment provides essential information needed to explain the timing and occurrence of the large submarine landslides on the SE Australian upper continental slope. While 
the tsunamigenic potential of these submarine landslides is unknown, they are certainly volumetrically large enough and occur at shallow enough water depths $(<1200 \mathrm{~m})$ to have the potential to generate substantial tsunamis that could cause widespread damage on the SE Australian coast and threaten coastal communities.

\section{$\underline{\text { References }}$}

Bardet JP, Synolakis, C.E., Davies, H.L., Imamura, F., Okal, E.A. (2003) Landslide Tsunamis: Recent Findings and Research Directions Pure and Applied Geophysics 160:1793-1809

Boyd R (2009) SS12/2008 Voyage Summary: Marine Geology and Geohazard Survey of the SE Australian Margin off Northern NSW and Southern Queensland. CSIRO,

Boyd R, Keene J, Hubble T, Gardner J, Glenn K, Ruming K, Exon N (2010) Southeast Australia: A Cenozoic Continental Margin Dominated by Mass Transport. In: Mosher DC, Moscardelli L, Baxter CDP et al. (eds) Submarine Mass Movements and Their Consequences, vol 28. Advances in Natural and Technological Hazards Research. Springer Netherlands, pp 491-502. doi:10.1007/978-90-481-3071-9_40

Clarke S, Hubble T, et al. (2011). Submarine landslides on the upper East Australian continental margin - preliminary findings. In: Submarine Mass Movements and Their Consequences (this issue). Advances in Natural and Technological Hazards Research. Springer Netherlands.

Glenn K, Post A, Keene J, Boyd R, Fountain L, Potter A, Osuchowski M, Dando N, Party S (2008) NSW Continental Slope Survey Post Cruise Report vol Geoscience Australia, Record 2008/14, 160pp.

Hampton MA, Locat J, Lee HJ (1996) Submarine landslides. Reviews of Geophysics 34:33-59

Jenkins CJ, Keene JB (1992) Submarine slope failures on the southeast Australian continental slope. Deep Sea Research 39:121-136

Locat J, Lee, HJ (2002) Submarine landslides: advances and challenges. Canadian Geotechnical Journal 39:193-212

Mosher DC, Moscardelli L, Baxter CDP et al. (2010) Submarine Mass Movements and Their Consequences, vol 28. Advances in Natural and Technological Hazards Research. Springer Netherlands. 

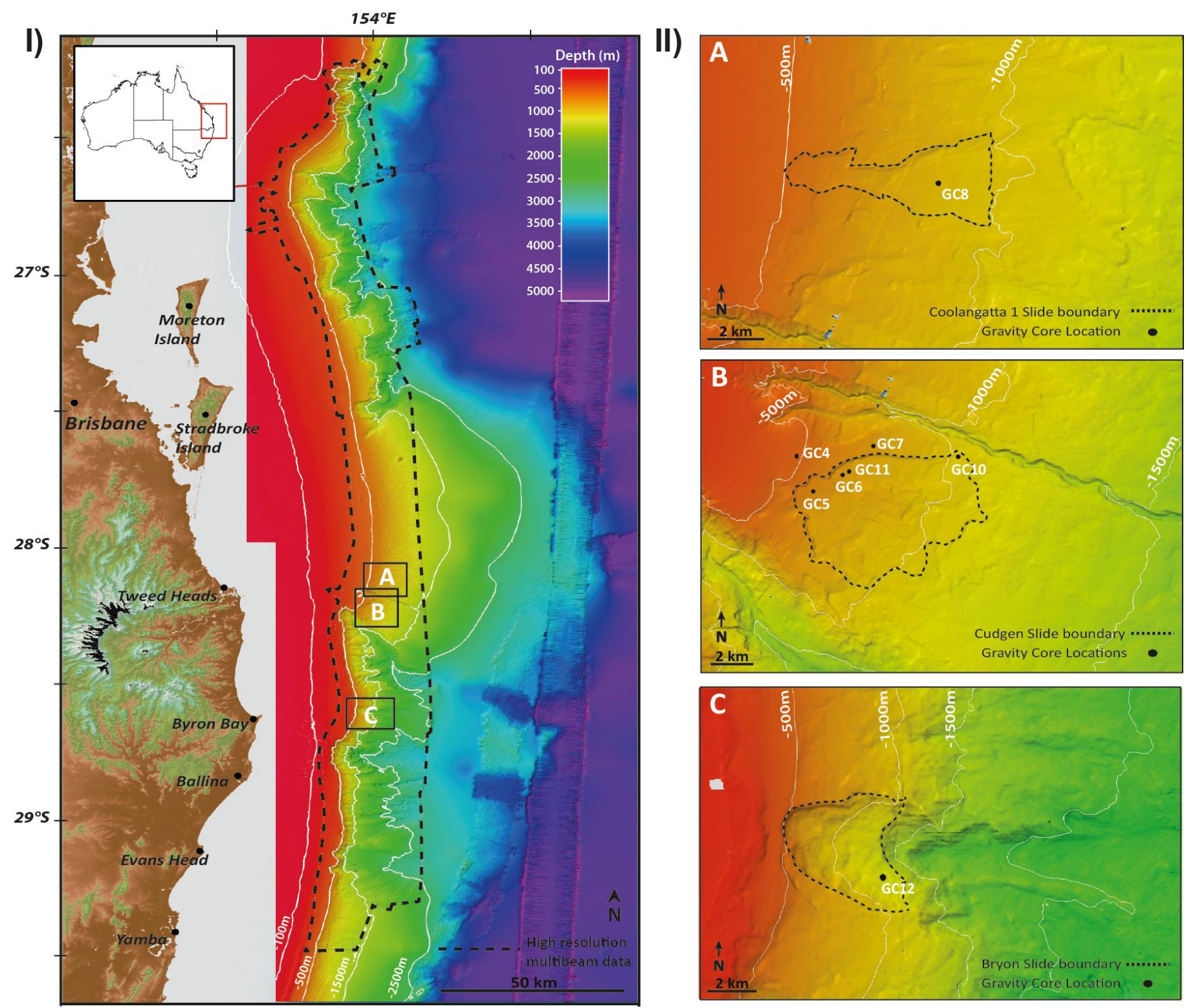

Figure 1 I) Location map of the southern Queensland to northern New South Wales coastline and bathymetry, showing the location of the study area (dashed line). Insets mark the three slides sites (north to south): (A) Coolangatta 1 Slide, (B) Cudgen Slide, (C) Byron Slide. II) The three slide sites showing the locations of 8 gravity cores (GC) collected on the RV Southern Surveyor (SS2008/12) voyage. 


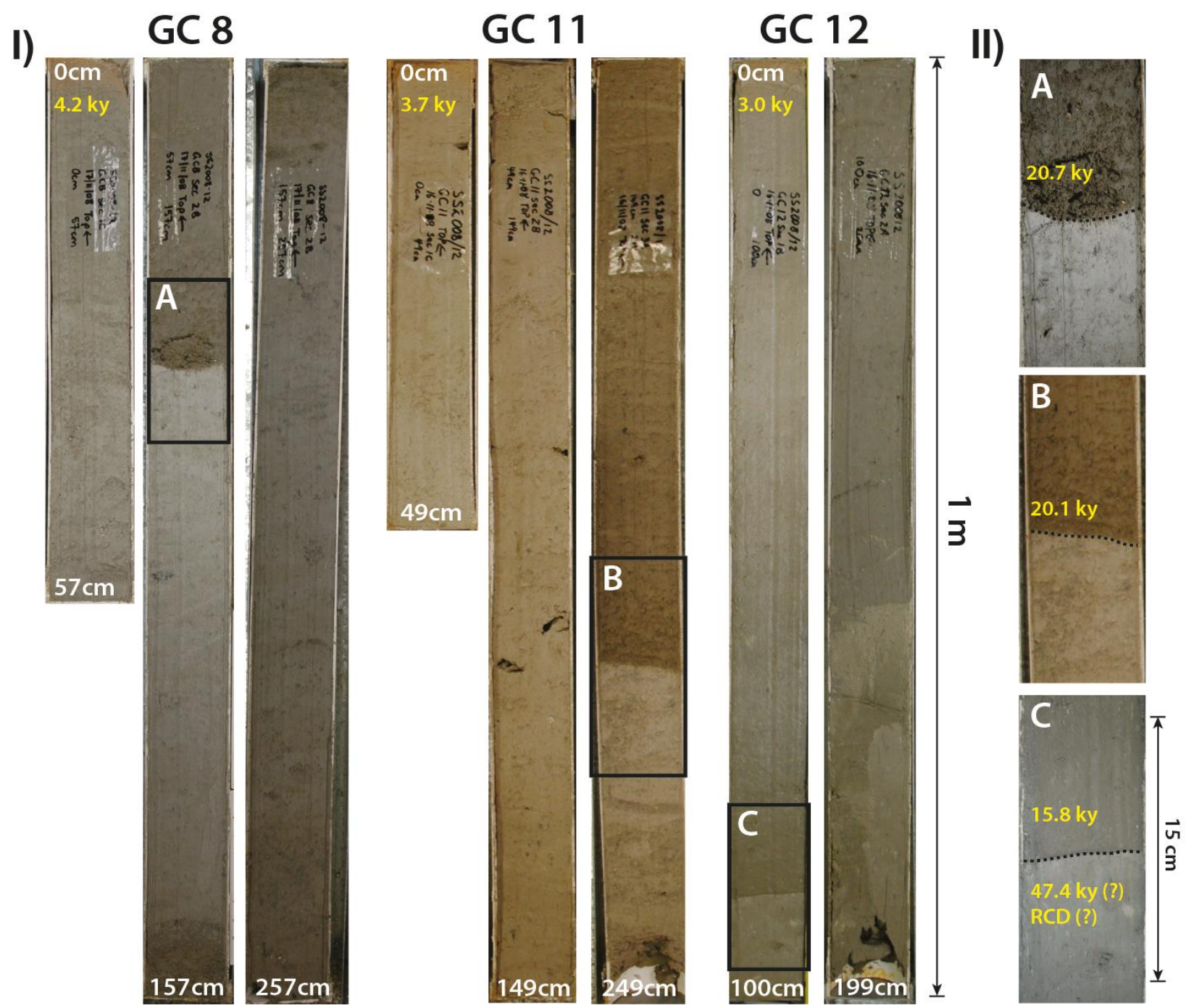

Figure 2 I) Images of the three gravity cores (GC) that present boundary features: GC8, GC11 and GC12. See Figure 1 for the locations of the gravity cores. II) Close up of the boundary feature in each core. The inferred slide plane is indicated with a dashed black line. Bulk radiocarbon ages for each core are also shown in yellow ( $k y=$ thousand years before present, $R C D=$ radiocarbon dead). 